\title{
Comparative performance of foreign and domestic family firms in Czech Republic
}

\author{
Ondřej Machek \\ University of Economics \\ Prague, Czech Republic \\ ondrej.machek@vse.cz
}

\begin{abstract}
A number of previous studies have been focused on performance differences research. The goal of this paper is to investigate the performance differences between domestic and foreign family firms operating in Czech Republic. We hypothesize that foreign family firms outperform their Czech counterparts in terms of return on assets and labor productivity. Using the Student's t-test for mean differences, regression analysis and matched-pair testing on the sample of 573 domestic and 154 foreign family firms, we found that foreign family firms outperform domestic family firms in profitability and labor productivity. One of the major factors explaining these performance gaps is the size and capital intensity of foreign family firms. We argue that the aspect of "foreignness" has been neglected in past family business studies dealing with performance of family firms, and that it actually makes a difference. Researchers should concern whether family firms in their research samples are wholly or partially foreignly owned or controlled.
\end{abstract}

Received

October, 2015

1 st Revision:

Keywords: Family business; Foreign family firms; Domestic family firms; Performance; Czech Republic

JEL Classification: L22, M10

\section{INTRODUCTION}

A number of previous research studies evaluated the differences between multinational companies and their domestic counterparts. Researchers evaluated various distinguishing factors, such as productivity, wages, profitability, growth, market-entry strategies, survival, market shares, or innovatory activities (Bellak, 2004). However, the question of performance gaps between foreign and domestic firms has been neglected in family business literature. At the same time, while family business research has been concerned with a lot of country-specific studies (Zahra, 2003; Lee, 2006; Allouche et al., 2008, among others), researchers seldom dealt with the issues of foreign control of firms in their research samples.

Family firms in transition countries, including the post-socialist countries of Central and Eastern Europe, represent a promising area of contemporary management research. A number of newly founded 
family firms emerged after the fall of the Iron Curtain in 1989, and some 25 years later, it is quite common that owners are transferring their businesses to the next generation.

In this article, we focus on family firms in Czech Republic. This country, whose population was last recorded at 10.5 million people in 2015 , represents on the most successful post-socialist countries in terms of market economy development. A number of foreign businesses are operating in the country, especially from the Netherlands, Germany, and Austria. Many of them are foreign family firms and represent a source of disruptive competition. At the same time, a significant part of Czech firms are family businesses too. However, the actual share of family firms in Czech economy is still unknown.

Since there is no comprehensive database of Czech family firms to date, and the very definition of family firms is far from being standardized, the identification of family firms represents a formidable task. One of the possible approaches to identify family firms is the surname matching approach (Hnilica and Machek, 2014). This approach is based on the systematic matching of surnames of people officially listed among family owners, managers, or members of supervisory board. At the same time, the algorithm provides as a "byproduct" a list of family firms which are not of Czech origin. Due to different historical development, cultural background and management practices, foreign family firms will be different from domestic family firms. The goal of this paper is to examine the following research question: Do domestic family firms perform better or worse as compared to their foreign counterparts?

This article is organized in the following way. First, we provide a review of relevant literature and formulate the research hypotheses. Then, we present the data and the methods used. Subsequently, we present and discuss the findings. Finally, concluding remarks are presented.

\section{LITERATURE REVIEW}

The literature review is focused on the following issues: the relationship between internationalization and performance, the internationalization of family business and determinants of their performance, and the specifics of Czech family firms which may affect performance as compared to foreign family firms.

\subsection{Internationalization and Performance}

To investigate the relationship between internationalization and performance, multiple approaches can be found in the past literature. They used multiple measures of internationalization, which range from simple indicators (ratio of foreign sales to total assets, number of countries in which a firm operates) to more complex indicators (for instance, the internationalization scale of Sullivan, 1994). However, past studies present mixed findings. While some studies found a positive (linear) relationship between internationalization and performance (for instance, Grant, 1987), other researchers presented the opposite findings (Denis et al., 2002). According to Lu and Beamish (2001), there is a U shaped relationship between internationalization and performance, but according to Hitt et al. (1997), there exists an inverted U-shaped relationship. Past research presents inconsistent findings.

Intuitively, there is a good reason to believe that firms which enter a foreign market own a significant competitive advantage. Among the possible sources of this advantage, we may find the background of parent company, economies of scale (Teece, 1980), access to lower input costs, or different technologies and capabilities, among others. On the other hand, domestic firms, especially in transition countries, being exposed to increased competitive pressures, have to adapt to the "world class" in order to remain competitive (Bowen and Wiersema, 2005). Foreign firms face local uncertainties which represent opportunities but also threats 
(Hitt et al, 1999), but firm-specific advantages (Koutsoyiannis, 1982) and the very multinationality of firms itself seem to offset disadvantages.

Performance gaps between domestic and foreign firms are not a new topic of research. Foreign firms have been found to perform better than local firms in developing countries (e.g. Willmore, 1986) but also in developed countries. For instance, Buckley and Casson (1976) found that in UK, multinational companies had higher labor productivity and were more profitable. Bellak (2004) reviewed past studies on performance gaps between foreign enterprises and their domestic counterparts. He argues that performance differences are due to being a multinational rather than the nationality of the firm, and that foreign ownership is less important explanatory variable than usually assumed.

However, although the question of performance differences between foreign and domestic firms has been addressed by past research, the same is not true for family business research. As far as we know, no study focused on performance gaps between foreign and domestic family firms. While not all foreign firms are family firms, family firms represent an important subset of them. And since the fact of "being foreign" is known to have effects on performance, the question whether it plays role in performance of family firms also deserves academic attention.

\subsection{Family Firms, their Internationalization and Performance}

One of the major issues of family business research is the fact that the term "family firm" is not standardized. Definitions of family firms can be divided into "essence" and "involvement" criteria (De Massis et al., 2012). While the "essence" approach includes the "intention for succession", self-identification as a family business, or behavioral aspects as distinguishing factors of family firms (Chua et al., 1999; Habbershon and Williams, 1999), the "involvement" approach deals with the involvement of family in different areas of control over a company, especially in three dimensions of family control (De Massis et al., 2012): ownership, management, and supervisory boards. Consistently with most past family business studies, we adopt the "involvement" approach to identify family firms in this study.

Family firms are supposed to seek to achieve not only economic goals, but also family-centered goals (Stafford et al., 1999) such as providing employment to family members, enhancing socio-emotional wealth, or maintaining family cohesion. However, according to Gallo and Sveen (1991), the internationalization process can affect the goals and culture of family firms. Family firms are also supposed to be subject to lower agency costs (Carney, 2005). These, together with different goals, and greater risk aversion (Schulze et al., 2003) affect the behavior of family firms, including their greater emphasis on long-term value maximization (Kachaner et al., 2012).

Family firms, just like other firms, see opportunities in international markets, so they become involved in international activities. Internationalization involves not only exporting, but also establishing joint ventures, strategic alliances, or foreign direct investment (FDI). However, the essence of family businesses may discourage family firms from seeking international opportunities. One of the basic reasons is the above-mentioned risk aversion of family firms; involvement in international trade is associated with a loss of control. Multiple authors found evidence of lower involvement of family firms in international markets (for instance, Graves and Thomas, 2004). The way family firms enter foreign market seems to be different; according to Bloch et al. (2012) family firms achieve foreign growth organically and are more patient once they enter a foreign market than non-family firms.

Okoroafo and Koh (2009) argue that family firms do not perceive enough the benefits of internationalization. On the other hand, Claver et al. (2008) found that family firms experienced the risk associated with internationalization more strongly than non-family firms. Fernández and Nieto (2006) found that family 
firms had difficulties in building a portfolio of strategic resources, which had negative impact on their international success. However, past research also suggests that family firms which decide to internationalize are older, larger and more sophisticated (Zahra, 2003). A similar finding was provided by Menéndez-Requejo (2005), who found that next-generation family firms internationalize better. To sum up, family firms generally seem to be reluctant to internationalization, but the firms that do decide to internationalize can be supposed to perform well and thus can become stronger competitors for local, domestic firms.

Besides internationalization, there are also other determinants of family firm performance which have to be taken into account in comparative analyses. Among them, we may cite succession; past research suggests that family owners can restrict growth in order to maintain control over the firm within the family (Daily and Dollinger, 1992). However, a number of authors such as Molly et al. (2010) found no significant relationship between succession and profitability. Important determinants of family firm performance will also include industry affiliation (due to different level of risk or market imperfections, among others) and firm age, which are commonly included control variables in family business studies (Lindow, 2013). Also, firm size is known to have effect on family business performance (Barbera, 2013; Li and Zhu, 2015), especially because of economies of scale and creating of barriers to entry.

Another determinant of performance is the level of debt. Employing more debt is associated with increased financial costs. Therefore, we assume a negative relationship between leverage and accounting profitability (Cassar and Holmes, 2003; Kyereboah-Coleman, 2007; Dempsey et al., 2012). On the other hand, past research suggests that there is no clear relationship between leverage and labor productivity (see e. g. Maçãs Nunes et al., 2007).

\subsection{Czech Family Firms}

While the true role of family firms in the Czech Republic is still unknown, past research suggest that there are differences between family and non-family firms, which are similar to the differences worldwide; in particular, family firms seem to use less debt and to be more profitable (Machek and Hnilica, 2015).

While we have no reason to believe that the inherent properties of Czech family firms are different from family firms in other countries, we can be almost sure that there are differences in management practices between Czech and foreign firms, due to different cultural, social, technological, economic, or political environment. Indeed, it is known that there exist significant differences between countries in terms of management practices (Bloom and Van Reenen, 2010) and corporate governance structures are largely national (Buckley, 1997). Although the question whether "home country" plays a role in explaining performance gaps between domestic and foreign firms is not clear cut (Bellak, 2004), firms coming from the world's most developed economies (such as Netherlands or Germany) can be assumed to have better management practices than firms operating in transition countries including the Czech Republic. In this context, it should also be noted that in the Schengen area, many obstacles to international trade have long been eliminated, which facilitates the operations of foreign firms on the Czech market.

Taking into account all the above mentioned arguments, we suppose that foreign family firms operating in the Czech Republic are mature firms with developed management practices which have carefully evaluated the benefits of internationalization and own a significant competitive advantage. Taking these arguments as a whole, then, we expect

H1: Foreign family firms operating in the Czech Republic have greater profitability than Czech family firms.

$\mathrm{H} 2$ : Foreign family firms operating in the Czech Republic have greater labor productivity than Czech family firms. 


\section{DATA AND METHODS}

\subsection{Data}

Our financial data were obtained from the Bureau van Dijks Amadeus database. In order to identify family firms, we used the surname matching approach (Hnilica and Machek, 2014). This approach is based on the fact that family members tend to have the same surname.

The definition of family firms used in this article is based on the "involvement" definitional criterion of family firms, which considers a firm to be a family firm if (De Massis et al., 2012):

- One or several families hold a significant part of the share capital;

- Family members retain significant control over the company, which depends on the distribution of capital and voting rights among nonfamily shareholders, with possible statutory or legal restrictions;

- Family members hold top management positions.

Consistently with this definition, we systematically matched surnames of people in three dimensions: management, ownership and supervisory boards. We focused on companies registered in the Czech Republic having more than 30 employees (i.e. especially large and medium-sized firms) and a greater turnover than 30 mil. Czech crowns (CZK). Companies with at least two people with the same surname in at least one of these boards were marked as "suspect of being family firms". Results were manually checked to eliminate possible mistakes. As a last step foreign and Czech family firms have been distinguished according to the domestic country of the owning or controlling family. In order to improve the comparability of the two groups, and since Czech family firms largely prevailed in the sample, we included only firms operating in the same industries as foreign family firms.

Table 1 displays the most frequently represented countries among foreign family firms operating in the Czech Republic.

Table 1

Ten most frequently represented countries among foreign family firms in the Czech Republic

\begin{tabular}{|l|c|}
\hline \multicolumn{1}{|c|}{ Country } & Frequency \\
\hline Germany & $41.48 \%$ \\
\hline Austria & $9.63 \%$ \\
\hline Netherlands & $5.93 \%$ \\
\hline France & $5.93 \%$ \\
\hline Italy & $4.44 \%$ \\
\hline Korea & $2.96 \%$ \\
\hline Switzerland & $2.96 \%$ \\
\hline Greece & $2.96 \%$ \\
\hline Poland & $2.96 \%$ \\
\hline Russia & $2.96 \%$ \\
\hline
\end{tabular}

Source: Author, according to Bureau van Dijk's Amadeus database.

We obtained a total of 573 Czech family firms and 154 foreign family firms with complete financial data from 2009-2013 operating in the same industries. To illustrate, table 2 displays the largest Czech and foreign family firms operating in the Czech Republic which were included in the sample. 
Ten largest domestic and foreign family firms operating in the Czech Republic

(name and approximate number of employees, 2014)

\begin{tabular}{|l|c|l|c|}
\hline \multicolumn{2}{|c|}{ Domestic family firms } & \multicolumn{2}{c|}{ Foreign family firms } \\
\hline Madeta & 1750 & Hyundai Motor Manufacturing Czech & 2750 \\
\hline Rosa Market & 1750 & Brose CZ & 2250 \\
\hline Mark2 Corporation Czech & 1750 & Lego Production & 1750 \\
\hline Hopi & 1750 & Ikea Ceska Republika & 1750 \\
\hline Dektrade & 1250 & Doosan Skoda Power & 1250 \\
\hline JIP Vychodoceska & 1250 & Bata & 1250 \\
\hline Ptacek-Velkoobchod & 1250 & H \& M Hennes \& Mauritz CZ & 1250 \\
\hline Al Invest Bridlicna & 1250 & ATALIAN CZ & 1250 \\
\hline GZ Media & 1250 & SODEXO & 1250 \\
\hline MP Krasno & 1250 & Heineken Ceska Republika & 750 \\
\hline
\end{tabular}

Source: Author, according to Bureau van Dijk's Amadeus database.

Since the population is unknown, we used a non-probabilistic convenience sampling based on availability instead of random sampling. It follows that the sample does not contain firms where family members are involved without being officially listed in ownership, management or control structure of firms. Also, the algorithm won't detect family firms where a married couple doesn't share the same surname.

\subsection{Methods}

In order to investigate performance differences between domestic and foreign family firms, we employ three approaches:

- Student's t-test for mean differences;

- Multiple regression analysis;

- Matched-pair testing.

The matched-pair investigation (see e.g. Allouche et al. 2008; McConaughy et al., 2001) is based on a systematic comparison of firms in pairs which have similar operating conditions. We created pairs of firms which operate in the same industry (as expressed by the four-digit NACE code) and have the closest size (assets) and age. Subsequently, a paired t-test was applied to compare the differences in means of selected variables. It follows that the number of pairs is equal to the number of foreign family firms which are less numerous in the sample.

\subsection{Measures}

One of the classical measures of performance is the return on assets (ROA), usually calculated as earnings before interest and taxes (EBIT) over total assets. In past studies on family business performance, it has been the most widely used measure of performance (Machek et al., 2013). We adopt this approach in this article as well and measure the dependent variable profitability using return on assets. We also measure labor productivity as total revenue over number of employees. 
The main independent variable whose effect we want to estimate is a binary variable foreign control that takes the value of one if the company is owned or led by people who don't originate from the Czech Republic, and zero if the company is owned or led by Czech citizens. Besides that, we take into account industry affiliation since performance of firms varies across industries. Industry affiliation is controlled using seven dummy variables which represent the following industries:

- Agriculture and mining;

- Manufacturing;

- Electricity, gas, steam and air conditioning supply; water supply; sewerage; waste management and remediation activities;

- Wholesale and retail trade; repair of motor vehicles and motorcycles;

- Transporting and storage;

- Accommodation and food service activities;

- Information and communication;

- Other industries.

Because performance of firms depends on the stage of its lifecycle and economies of scale, we also control for firm size (measured by the natural logarithm of total assets) and firm age (by 2013). We also control for capital structure which is measured by gearing (debt-to-equity ratio). We decided not to control for other variables to avoid multicollinearity issues. The analysis does not control for "country of origin" of foreign family firms for two reasons: first, according to Bellak (2004), performance differences are explained by the fact of being a multinational (foreign control dummy variable) rather than by firm nationality; second, the range of nationalities of foreign family firms is very broad (we identified 24 nationalities, see Table 1 for the ten most frequently represented ones).

Financial variables were measured using mean values from 2009-2013 to eliminate year-to-year variations.

\section{RESULTS}

All statistical analyses were performed in the Stata 14 software. Table 3 provides descriptive statistics for all dependent and independent variables (except industry dummies). Obviously, sample distributions are skewed to the right, and some of the variables have a relatively large spread about the mean.

Table 3

Descriptive statistics

\begin{tabular}{|l|c|c|c|c|c|c|}
\hline \multirow{2}{*}{ Variable } & \multicolumn{3}{c|}{ Domestic FBs (N=573) } & \multicolumn{3}{c|}{ Foreign FBs (N=154) } \\
\cline { 2 - 7 } & Mean & Std. Dev. & Median & Mean & Std. Dev. & Median \\
\cline { 2 - 8 } & 0.054 & 0.075 & 0.044 & 0.067 & 0.104 & 0.042 \\
\hline Profitability & 2.712 & 5.423 & 1.497 & 4.836 & 8.759 & 2.194 \\
\hline Labor productivity & 11.484 & 1.257 & 11.394 & 12.225 & 1.546 & 12.207 \\
\hline Firm size & 17.147 & 4.854 & 18.000 & 17.344 & 5.306 & 19.000 \\
\hline Firm age & 0.734 & 1.074 & 0.382 & 0.709 & 1.335 & 0.202 \\
\hline Gearing & & & & & \\
\hline
\end{tabular}

Source: Own calculations. 


\subsection{Test for Mean Differences}

Since the sizes of samples differ, as well as their variances, we used the Student's t test for mean differences with unequal variances. Student's t-test assumes normality of population distributions. However, since the size of sample is large enough, the sampling distributions of sample means have approximately normal distributions. Student's t-test is robust on this assumption violation for large sample sizes. In table 4, we display the results for the two response variables and three control variables.

Foreign family firms seem to enjoy greater return on assets than domestic (Czech) family firms. However, the results are only moderately significant (at the 0.1 level). Foreign family firms also seem to outperform domestic family firms in terms of labor productivity (significant at the 0.01 level). We found only moderate support for the hypothesis $\mathrm{H} 1$ and a stronger support for the hypothesis H2. Also, foreign-owned family firms operating in the Czech Republic seem to be larger than domestic family firms (significant at the 0.01 level). The other results are not statistically significant. However, one of the drawbacks of this approach is the fact that $\mathrm{t}$-test does not control for operating conditions and provides only limited insight into the real performance gaps.

Table 4

t-test for mean differences

\begin{tabular}{|l|c|c|c|c|c|}
\hline \multicolumn{1}{|c|}{ Variable } & Mean domestic & Mean foreign & $\begin{array}{c}\text { Mean } \\
\text { difference }\end{array}$ & t statistics & p-value \\
\hline Profitability & 0.054 & 0.067 & -0.013 & $-1.519^{*}$ & 0.065 \\
\hline Labor productivity & 2.712 & 4.836 & -2.123 & $-2.691^{* * *}$ & $<0.01$ \\
\hline Firm size & 11.484 & 12.225 & -0.741 & $-6.513^{* * *}$ & $<0.01$ \\
\hline Firm age & 17.147 & 17.344 & -0.197 & -0.443 & 0.329 \\
\hline Gearing & 0.734 & 0.709 & 0.025 & 0.247 & 0.597 \\
\hline
\end{tabular}

*** - significant at the 0.01 level (one-tailed), ${ }^{*}$ - significant at the 0.1 level (one-tailed)

Source: Own calculations.

\subsection{Regression Results}

When performing regression analysis, we also had to deal with heteroskedasticity which does not affect coefficient estimates, but raises concern about the standard errors. Our regression model uses heteroskedasticity-consistent standard errors following Davidson and MacKinnon (1993). There are no multicollinearity issues.

Table 5 displays the regression results for all independent variables (except the seven dummy variables representing industry affiliation). In the same table, we present regressions for profitability as well as labor productivity.

The results do not support the hypothesis $\mathrm{H} 1$; although the coefficient of foreign control is positive, the results are not significant at the 0.1 level. Profitability is negatively influenced by the level of debt (significant at the 0.01 level). The right part of table 5 displays regression results for labor productivity. In this case, the results support the hypothesis $\mathrm{H} 2$ : foreign control positively affects labor productivity (significant at the 0.1 level). Productivity is also positively influenced by firm size (significant at the 0.01 level). Gearing has no significant effect on labor productivity. 
Table 5

Regression results

\begin{tabular}{|l|c|c|c|c|c|c|}
\hline \multirow{2}{*}{ Variable } & \multicolumn{3}{|c|}{ Profitability } & \multicolumn{3}{c|}{ Labor productivity } \\
\cline { 2 - 7 } & Coeff. & t statistics & p-value & Coeff. & t statistics & p-value \\
\hline Intercept & $0.108^{* * *}$ & 3.190 & 0.001 & $-6.991^{* * *}$ & -3.520 & $<0.01$ \\
\hline Foreign & 0.014 & 1.550 & 0.121 & $1.293^{*}$ & 1.770 & 0.077 \\
\hline Firm age & -0.00001 & -0.130 & 0.899 & -0.110 & -1.640 & 0.102 \\
\hline Firm size & -0.003 & -1.230 & 0.218 & $0.973^{* * *}$ & 3.820 & $<0.01$ \\
\hline Gearing & $-0.015^{* * *}$ & -6.830 & $<0.01$ & 0.203 & 0.630 & 0.540 \\
\hline
\end{tabular}

${ }^{* * *}$ - significant at the 0.01 level, ${ }^{* *}$ - significant at the 0.05 level, ${ }^{*}$ - significant at the 0.1 level. Besides the above variables, regression included 7 dummy variables to control for industry affiliation.

\section{Source: Own calculations.}

\subsection{Matched-pair Testing}

As previously mentioned, we created pairs of foreign-domestic family firms which operate in the same industry and have the closest age and size. This approach controls for external influences and improves the comparability of the two groups of family firms. Subsequently, a paired t-test was applied (see Table 6). The results provide some support for the research hypotheses; foreign family firms seem to enjoy better profitability (significant at the 0.05 level) at labor productivity (significant at the 0.1 level). They also seem to be larger than domestic family firms (significant at the 0.01 level) which is consistent with our previous results.

Table 6

Matched-pair testing: Foreign vs domestic family firms

\begin{tabular}{|l|c|c|c|}
\hline \multicolumn{1}{|c|}{ Variable } & Difference in means & t statistics & p-value \\
\hline Profitability & -0.022 & $-2.05^{* *}$ & 0.021 \\
\hline Labor productivity & -1.635 & $-1.597^{*}$ & 0.056 \\
\hline Firm size & -0.578 & $-4.290^{* * *}$ & $<0.01$ \\
\hline Firm age & 0.157 & 0.508 & 0.306 \\
\hline Gearing & 0.004 & 0.025 & 0.489 \\
\hline
\end{tabular}

${ }^{* * *}$ - significant at the 0.01 level (one-tailed), ${ }^{* *}$ - significant at the 0.05 level (one-tailed), ${ }^{*}$ - significant at the 0.05 level (one-tailed).

Source: Own calculations.

\section{DISCUSSION}

Taking into account the results, we found moderate support for the hypothesis $\mathrm{H} 1$ and a stronger support for H2. Foreign family firms operating in the Czech Republic seem to outperform domestic family firms especially in terms of labor productivity.

One of the distinguishing factors which can explain the differences can be the value of total assets. There are two main reasons why it should matter in performance: firm size and capital intensity. 
Foreign family firms seem to be significantly larger than domestic family firms, and size seems to positively affect their productivity. Factors such as market power and greater access to capital markets (Baumol, 1967) can contribute to the success of larger firms. And since foreign family firms operating in the Czech Republic are larger, another reason of their better performance can be the fact that large firms are better able to capture niche markets, while medium-sized firms are "stuck in the middle" (Amato and Amato, 2004).

Another economic factor explaining performance gaps may be the higher capital intensity, which is an important force behind an increase in productivity (Bellak, 2004), and also may lead to higher profitability. In order to examine this factor, we performed a simple correlation analysis between labor productivity and capital intensity as measured by assets per employee. The results suggest that there is a significant correlation between these two variables $(0.73$ for domestic firms, 0.68 for foreign firms, both significant at the 0.05 level).

The role of age in explaining performance gaps is not clear. Mature industries tend to have declining profits, and young affiliates of foreign family firms can have high start-up and restructuring costs (Bellak, 2004). In our study, firms coming from abroad may have been founded much longer time ago than expected, since the date of incorporation merely states when the affiliate has been founded in the Czech Republic, not in the country of origin. In this context, and when taking into account that it is only 25 years after transition to market economy, foreign family firms operating in the Czech Republic can supposed to be much older and more experienced.

Foreign family firms in our sample have a common property: all of them are able to successfully internationalize. On the other hand, only a part of Czech family firms actually operates on foreign markets and they have only a limited experience after 25 years of the fall of the iron curtain. From this viewpoint, foreign family firms can be seen as mature firms which are able to devote a significant part of their resources to support their foreign subsidiaries, thus obtaining a competitive advantage having a favorable impact on profitability and labor productivity. On the other hand, Czech family firms may have failed to adopt the "best practice technology" (see e.g. Maliranta, 1997). Generally, we may suppose that the following advantages of multinational companies mentioned in the past literature may also contribute to the performance gaps (Bellak, 2004):

- Better access to foreign markets through intra-firm trade and network economies;

- Drawing the managerial expertise of the parent company;

- More extensive set of information and better capacity for evaluating different situations;

- Access to superior technology.

Last but not least, gearing (level of debt) seems to negatively affect profitability of both domestic and foreign family firms, but it has no significant effect on labor productivity. These findings are consistent with prior research (Cassar and Holmes, 2003; Kyereboah-Coleman, 2007; Dempsey et al., 2012; Maçãs Nunes 2007). The results of this study suggest that domestic and foreign family firms in the Czech Republic are not different in terms of debt utilization.

\section{CONCLUSION}

While a vast number of comparative family business studies dealt with performance of family firms, in many cases it wasn't clear whether authors analyzed purely domestic or all family firms operating in a specific country. We also didn't find any study that analyzed the differences between domestic and foreign family firms. Since we account for such "national" heterogeneity among family firms, this article presents a theoretical contribution to the family business literature. 
The research extends prior research and suggests that foreign family firms operating in the Czech Republic seem to perform better than domestic family firms. Domestic family firms may have failed to imitate the best practice technology.

From the policy point of view, many countries establish policies for attracting foreign investors, which should bring benefits to the economy that are difficult to attain by domestic firms. These policies will be more efficient if foreign firms are performing better than domestic firms. If the negative effect of "market stealing" is offset by the positive "technology spillover" effect (Kosova, 2010), the support of foreign multinationals can contribute to the development of the economy. The spillover effect includes not only technology, but also knowledge externalities. Knowledge on family business, including governance, strategy formulation, succession planning, and other issues of family business management are still missing in the Czech Republic. Therefore, our research provides some justification for granting preferential investment incentives to foreign firms.

Many countries also adopt policies to support family entrepreneurship. Such policies are still lacking in the Czech Republic. As an epiphenomenon, there are still no official statistics focused on family businesses in this country (Machek and Hnilica, 2013).

Besides the findings presented in the previous section, we also want to emphasize that determining the "nationality" of a family firms is not always straightforward; a significant part of a "local" family business may be owned by a foreign persons. Therefore, our research also highlights that the outcomes of past family business studies can be biased by the fact that family firms included in research samples could have been partially or wholly owned or managed by foreigners or foreign legal persons. Our results suggest that such firms, however, perform differently and may have different management practices and sources of competitive advantage. This is true especially in the Czech Republic, but also in other post-socialist countries. To sum up, we argue that the aspect of "foreignness" has been neglected in past family business studies dealing with performance of family firms, and that foreignness actually does make a difference. Therefore, researchers should deal with the question whether family firms in their research samples are purely domestic, or wholly or partially foreign - in terms of ownership, management and control.

However, this study also has some limitations. Our non-probability sampling may have caused the undercoverage of some population groups. On the other hand, since there is no official database of Czech family firms, we believe that currently, surname matching is the only possible way how to obtain a larger sample of family firms. The second limitation is the regional focus of the study; our sample contains only family firms operating in the Czech Republic. While this can be seen as a weakness, we believe it is also one of the strength, since the literature has been relatively silent on family business issues in post-socialist European countries so far.

In future research, similar analyses should be carried out in other countries in order to verify our findings. Also, researchers should address the questions "why" and "how" local and foreign family firms in particular countries differ, which will require qualitative research.

\section{REFERENCES}

Acocella, N. (1992), The Multinational Firm and the Theory of Industrial Organization, in Del Monte, A. (ed.), Recent Developments in the Theory of Industrial Organization, London: Macmillan.

Allouche, J., Amann, B., Jaussaud, J., and Kurashina, T. (2008), The Impact of Family Control on the Performance and Financial Characteristics of Family versus Nonfamily Businesses in Japan: A Matched-Pair Investigation, Family Business Review, Vol. 21, no. 4, pp. 315-329. 
Amato, L. J. and Amato, C. H. (2004), Firm size, strategic advantage, and profit rates in US retailing, Journal of Retailing and Consumer Services, Vol. 11, no. 3, pp. 181-193.

Barbera, F. (2013). Financing, firm size and productive efficiency: the effect of family ownership. Doctoral dissertation, Bond University, Australia.

Baumol, W. (1967), Business behavior value and growth, New York: Harcourt Brace Jovanovich.

Bellak, C. (2004), How domestic and foreign firms differ and why does it matter? Journal of economic surveys, Vol. 18, no. 4, pp. 483-514.

Bloch, A., Kachaner, N., and Stalk, G. (2012), What you can learn from family business. Harvard Business Review, Vol. 90, no. 11, pp. 1-5.

Bloom, N. and Van Reenen, J. (2010), Why do management practices differ across firms and countries? The Journal of Economic Perspectives, Vol. 24, no. 1, pp. 203-224.

Bowen, H. P. and Wiersema, M. F. (2005), Foreign-based Competition and Corporate Diversification Strategy, Strategic Management Journal, Vol. 26, no. 12, pp. 1153-1171.

Buckley, P. J. and Casson, M. (1976), The future of the multinational enterprise, London: Macmillan

Buckley, P. J. (1997), Cross-border governance in multinational enterprises, in Buckley, P. J. (ed.), Multinational Firms, Cooperation and Competition in the World Economy, Basingstoke: Macmillan Press, 289-304.

Carney, M. (2005), Corporate governance and competitive advantage in family-controlled firms, Entrepreneurship: Theory \& Practice, Vol. 29, no. 3, pp. 249-265.

Cassar, G., and Holmes, S. (2003), Capital structure and financing of SMEs: Australian evidence, Accounting \& Finance, Vol. 43, no. 2, pp. 123-147.

Chua, J. H., Chrisman, J. J., and Sharma, P. (1999), Defining the family business by behavior, Entrepreneurship Theory and Practice, Vol. 23, no. 4, pp. 19-40.

Claver, E., Rienda, L., and Quer, D. (2008), Family firms' risk perception: Empirical evidence on the internationalization process, Journal of Small Business and Enterprise Development, Vol. 15, no. 3, pp. 457-471.

Daily, C. M., and Dollinger, M. J. (1992). An empirical examination of ownership structure in family and professionallymanaged firms, Family Business Review, Vol. 5, no. 2, pp. 117-136.

Davidson, R., and MacKinnon, J. G. (1993), Estimation and Inference in Econometrics, New York: Oxford University Press.

Dempsey, S. J., Harrison, D. M., Luchtenberg, K. F., and Seiler, M. J. (2012), Financial opacity and firm performance: the readability of REIT annual reports, The Journal of Real Estate Finance and Economics, Vol. 45, no. 2, pp. 450-470.

Denis, D. J., Denis, D. K., and Yost, K. (2002), Global diversification, industrial diversification, and firm value, Journal of Finance, Vol. 57, no. 5, pp. 1951-1979.

Molly, V., Laveren, E., \& Deloof, M. (2010), Family business succession and its impact on financial structure and performance, Family Business Review, Vol. 23, no. 2, pp. 131-147.

Fernandez, Z. and Nieto, M. J. (2006), Impact of ownership on the international involvement of SMEs, Journal of International Business Studies, Vol. 37, no. 3, pp. 340-351.

Gallo, M. and Sveen, J. (1991), Internationalizing the Family Business: Facilitating and Restraining Factors, Family Business Review, Vol. 4, no. 2, pp. 181-190

Grant, R. M. (1987), Multinationality and performance among British manufacturing companies, Journal of International Business Studies, Vol. 18, no. 3, pp. 79-89.

Graves, C., and Thomas, J. (2004), Internationalisation of the family business: a longitudinal perspective, International Journal of Globalisation and Small Business, Vol. 1, no. 1, pp. 7-27

Habbershon, T. G. and Williams, M. (1999), A resource-based framework for assessing the strategic advantages of family firms, Family Business Review, Vol. 12, no. 1, pp. 1-25. 
Hitt, M. A., Hoskisson, R. E., and Kim, H. (1997), International diversification: Effects on innovation and firm performance in product-diversified firms, Academy of Management Journal, Vol. 40, no. 4, pp. 767-768

Hitt, M. A., Ireland, R. D., and Hoskisson, R. E. (1999), Strategic Management: Competitiveness and Globalization, Cincinnati: South-Western College Publishing.

Hnilica, J., and Machek, O. (2014), Toward a Measurable Definition of Family Business: Surname Matching and its Application in the Czech Republic, International Advances in Economic Research, Vol. 21, no. 1, pp. 119-120.

Kachaner, N., Stalk, G., and Bloch, A. (2012), What You Can Learn from Family Business. Harvard Business Review, Vol. 90, no. 11, pp. 102-106.

Kosova, R. (2010), Do foreign firms crowd out domestic firms? Evidence from the Czech Republic, The Review of Economics and Statistics, Vol. 92, no. 4, pp. 861-881.

Koutsoyiannis, A. (1982), Non-Price Decisions: the firm in a modern context, London: Macmillan.

Kyereboah-Coleman, A. (2007), The impact of capital structure on the performance of microfinance institutions, The Journal of Risk Finance, Vol. 8, no. 1, pp. 56-71.

Lee, J. (2006), Family firm performance: Further evidence, Family business review, Vol. 19, no. 2, pp. 103-114.

Lee, J. (2009), Does size matter in firm performance? Evidence from US public firms, International Journal of the Economics of Business, Vol. 16, no. 2, pp. 189-203.

Li, L., and Zhu, B. (2015), Family involvement, firm size, and performance of private-owned enterprises, The Journal of Chinese Sociology, Vol. 2, no. 1, pp. 1-18.

Lindow, C. M. (2013), A strategic fit perspective on family firm performance. Wiesbaden: Springer Fachmedien.

Lu, J. W. and Beamish, P. W., (2001), The Internationalisation and Performance of SMEs, Strategic Management Journal, Vol. 22, no. 6-7, pp. 565-586.

Maçás Nunes, P., Neves Sequeira, T., and Serrasqueiro, Z. (2007), Firms' leverage and labour productivity: a quantile approach in portuguese firms, Applied Economics, Vol. 39, no. 14, pp. 1783-1788.

Machek, O. and Hnilica, J (2013), On the Performance Gaps between Family and Non-Family Firms in the Czech Republic, Central European Business Review, Vol. 2, no. 4, pp. 54-55.

Machek, O., Brabec, M., and Hnilica, J. (2013), Measuring Performance Gaps Between Family and Non-Family Businesses: A Meta-Analysis of Existing Evidence, International Academic Research Journal of Business and Management, Vol. 2, no. 3, pp. 17-30.

Machek, O. and Hnilica, J. (2015), Evaluating the Impact of Family Presence in Ownership and Management on Financial Performance of Firms Using Matched-Pair Investigation, Politická ekonomie, Vol. 63, no. 3, pp. $347-362$.

Maliranta, M. (2002), Plant productivity in the Finnish manufacturing. Characteristics of high productivity plants, discussion Paper No.612, Helsinki: The Research Institute of the Finnish Economy.

Massis de, A., Sharma, P., Chua, J. H., and Chrisman, J. J. (2012), Family Business Studies - an annotated bibliography, Cheltenham, UK: Edward Elgar Publishing.

McConaughy, D. L., Matthews, C. H., and Fialko, A. S. (2001), Founding Family Controlled Firms: Performance, Risk, and Value, Journal of Small Business Management, Vol. 39, no. 1, pp. 31-49.

Okoroafo, S. C. and Koh, A. C. (2009), Family Businesses' Views on Internationalization: Do they Differ by Generations? International Business Research, Vol. 3, no. 1, pp. p22.

Schulze, W. S., Lubatkin, M. H., and Dino, R. N. (2002), Altruism, agency, and the competitiveness of family firms, Managerial and Decision Economics, Vol. 23, no. 4-5, pp. 247-259.

Stafford, K., Duncan, K. A., Dane, S., and Winter, M. (1999), A research model of sustainable family businesses, Family Business Review, Vol. 12, no. 3, pp. 197-208.

Sullivan, D. (1994), Measuring the degree of internationalization of a firm, Journal of International Business Studies, Vol. 25, no. 2, pp. 325-342. 
Teece, D. J. (1980), Economies of scope and the scope of the enterprise, Journal of Economic Behavior and Organization, Vol. 1, no. 3, 223-247.

Willmore, L. N. (1986), The comparative performance of foreign and domestic firms in Brazil, World Development, Vol. 14 , no. 4, pp. 489-502.

Zahra, S. A. (2003), International expansion of US manufacturing family businesses: The effect of ownership and involvement, Journal of Business Venturing, Vol. 18, no. 4, pp. 495-512. 